\title{
Shear wave splitting in the Isparta Angle, southwestern Turkey: Anisotropic complexity in the mantle
}

\author{
Aslihan Şapaš and Aysun Boztepe-Güney \\ Department of Geophysical Engineering, Faculty of Mines, Istanbul Technical \\ University of Istanbul 34390, Maslak, Turkey. \\ *e-mail: sapasa@itu.edu.tr
}

\begin{abstract}
This study presents shear wave splitting analysis results observed at ISP (Isparta) broadband station in the Isparta Angle, southwestern Turkey. We selected 21 good quality seismic events out of nearly 357 earthquakes and calculated splitting parameters (polarization direction of fast wave, $\phi$ and delay time between fast and slow waves, $\delta t$ ) from mainly SKS and a few SKKS phases of the selected 21 seismic events. Then, we compared calculated splitting parameters at ISP station $\left(56^{\circ} \leq \phi \leq 205^{\circ} ; 0.37 \mathrm{~s} \leq \delta t \leq 4 \mathrm{~s}\right)$ with those previously calculated at ANTO (Ankara) and ISK (İstanbul) stations $\left(27^{\circ} \leq \phi \leq 59^{\circ} ; 0.6 \mathrm{~s} \leq \delta t \leq 2.4 \mathrm{~s}\right.$ and $\left.26^{\circ} \leq \phi \leq 54^{\circ} ; 0.6 \mathrm{~s} \leq \delta t \leq 1.5 \mathrm{~s}\right)$ which are located at 230 and $379 \mathrm{~km}$ away from ISP station in central and northwestern Turkey, respectively. The backazimuthal variations of the splitting parameters at ISP station indicate a different and complex mantle polarization anisotropy for the Isparta Angle in southwestern Turkey compared to those obtained for Ankara and İstanbul stations.
\end{abstract}

\section{Introduction}

The Isparta Angle (figure 1) is a triangular-shaped region with $120 \mathrm{~km}$ length along $\mathrm{N}-\mathrm{S}$ direction and $50 \mathrm{~km}$ width in the south (Glover and Robertson 1998). It is an important segment of the eastern Mediterranean region for the study of the lithospheric deformation for two main reasons. Firstly, it is located at the intersection of the southward-convex Aegean and Cyprus arcs. Secondly, it is located also at the boundary between central/eastern Anatolia and Aegean/western deformation areas (Reilinger et al 1997).

Faccenna et al (2006) have described the tectonic evolution of the Anatolian-Aegean block in three stages by using formation time of the North Anatolian fault (NAF) as a reference point (figure 2). The NAF is a right-lateral strike-slip fault zone with $1400 \mathrm{~km}$ length along E-W direction extending from Karlova triple junction (KTJ) in the east to the Aegean Sea in the west. It is also the northern boundary of the Anatolian-northern Aegean block. Before the formation of the NAF (Early-Middle Miocene), the Bitlis-Pontide collisional belt between Arabia and Eurasia plates in the east and the Aegean extension area in the west, were formed. During the formation of the NAF (Late Miocene-Pliocene), the Turkish-Iranian plateau was uplifted $(1.5-2 \mathrm{~km})$ and volcanism started. In the west, extension took place and the Aegean trench retreat developed. These tectonic conditions triggered the lateral escape of Anatolia from the east to the west and formed the NAF. After formation of the NAF (Late Pleistocenepresent day), the deformational pattern in the region has been locally different from the previous stages, a short-lived $\mathrm{N}-\mathrm{S}$ compression episode in Ionian islands, a strike-slip episode in south central Anatolia, a right-lateral strike-slip regime in the eastern part of the NAF and wide-spread heterogeneous extensional regime in south central Anatolia (NNE and NE).

Keywords. Shear wave splitting; polarization direction; mantle polarization anisotropy; SKS and SKKS phases; Isparta Angle. 


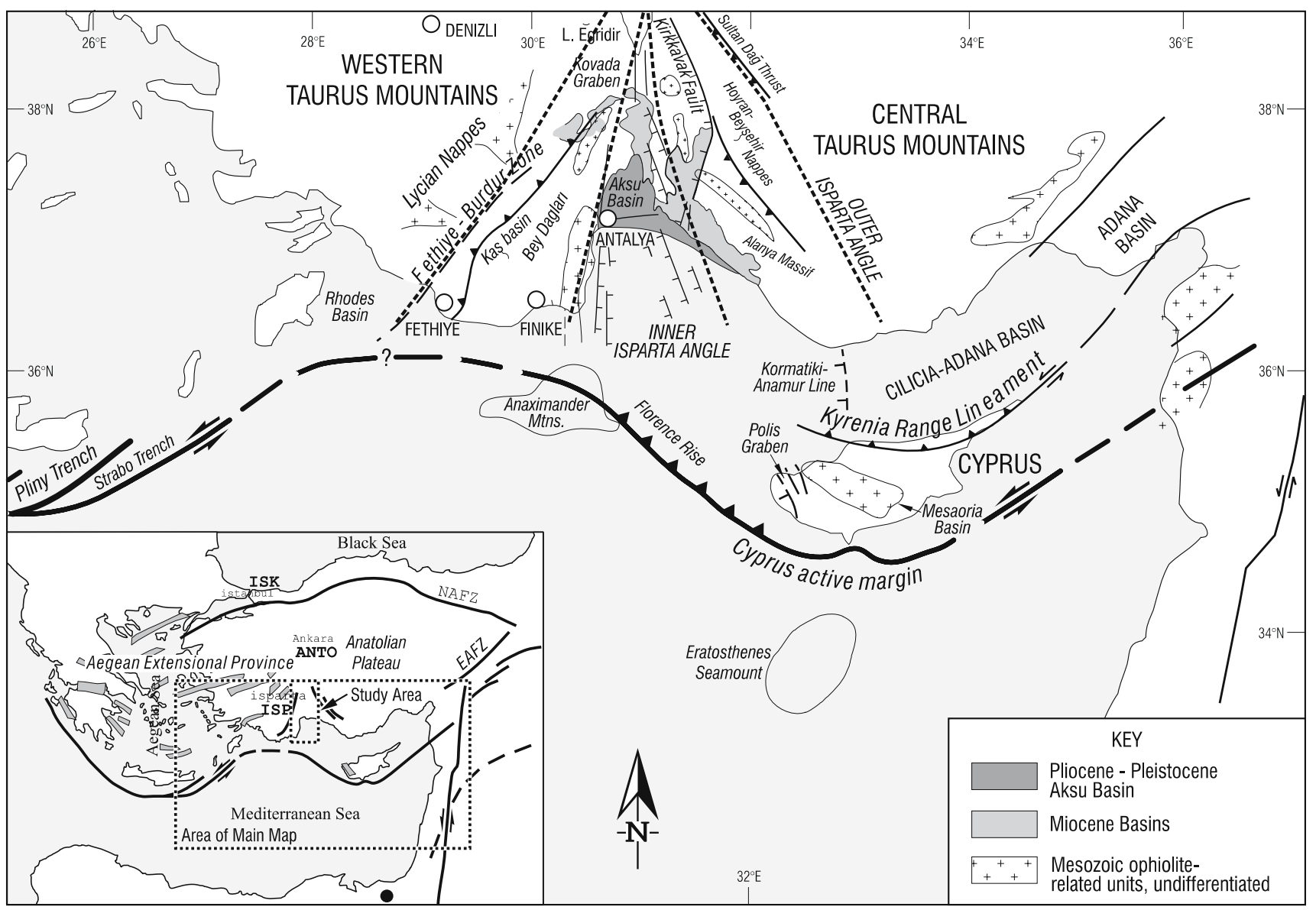

Figure 1. Map of tectonic setting of the Isparta Angle. Inset map shows two tectonic provinces bounding the Isparta Angle: the Aegean extensional province and the Anatolian plateau. The areas of the inner and outer Isparta Angle are shown by dotted lines. NAFZ: North Anatolian Fault Zone; EAFZ: East Anatolian Fault Zone (Glover and Robertson 1998). Map also shows the locations of the broadband stations used in this study (ISP) and those (ANTO and ISK) used in the studies presented by Şapaş and Boztepe-Güney (2005).

During tectonic evolution of the region in Late Miocene to Early Pliocene time, the Isparta Angle was situated between the Aegean extensional province $(\mathrm{N}-\mathrm{S})$ and rotational movement of the Anatolian plateau and experienced right lateral shear (figure 3a). Lycian Nappes replaced the Isparta Angle during Late Miocene time. A change in stress regime from $\mathrm{N}-\mathrm{S}$ to $\mathrm{NE}-\mathrm{SW}$ occurred in the Aegean province around Late Pliocene-Early Quaternary time (figure 3b). This also affected the tectonic evolution of the Isparta Angle and surroundings by the occurrence of presently active NW-SE trending asymmetrical graben system in the center and strong uplift of the Bey Dağları region of the Taurus Mountains in the west (figure 1). Glover and Robertson (1998) have mapped the directions of fault planes bounding both the limbs and the core of the Isparta Angle (figure 1). They have found that the fault directions are NE-SW, NW-SE to N-S and some intervening orientations. Based on stratigraphical and geomorphological evidence, they have dated the faults in the study area as reverse faults in Late Miocene age, right lateral faults in Late MioceneEarly Pliocene age and normal faults in Late Pliocene-recent age.

In the present day, a mean westward motion of Anatolia with respect to Europe is about $22 \mathrm{~mm} / \mathrm{yr}$ along the NAF. The speeds of the southern Aegean and the central Anatolian blocks are 30 and $20 \mathrm{~mm} / \mathrm{yr}$ (McClusky et al 2000). These two blocks are separated in western Anatolia by a N-S stretching area indicated by $\mathrm{E}-\mathrm{W}$ trending grabens (figure 2).

To establish a geodynamic model for Anatolia, investigation of the role of mantle flow is very important since the upper mantle lithosphere dynamics is mainly controlled by shear and normal tractions associated with both large-scale plate motions and with local mantle dynamics (Christensen 1984). We have here investigated the traces of past mantle deformation episodes affecting the Isparta Angle by using shear wave splitting (Savage 1999). Firstly, we have calculated 


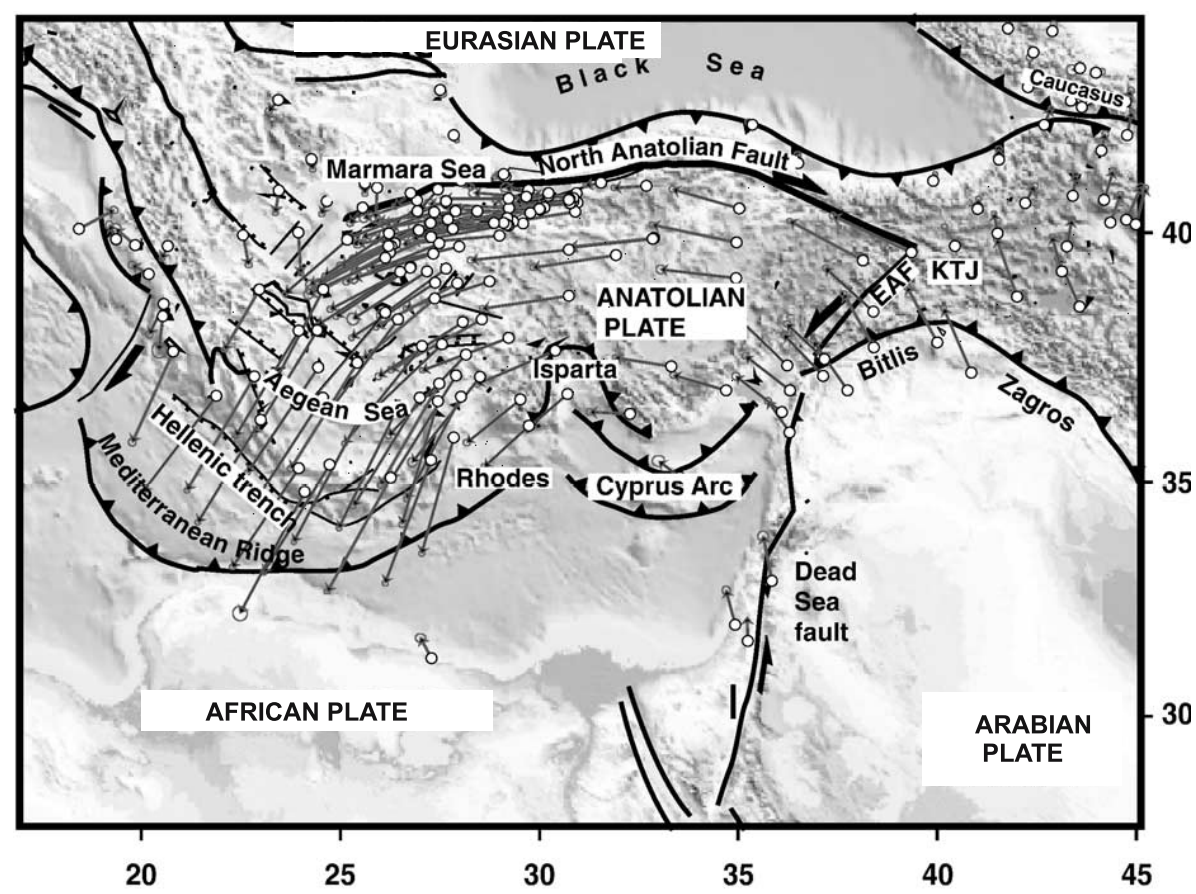

Figure 2. Tectonic map of the eastern Mediterranean-Middle East region. GPS vectors with respect to Eurasia are from McClusky et al (2000). Abbreviations: KTJ: Karlıova triple junction; EAF: East Anatolian Fault (Faccenna et al 2006).

(a)

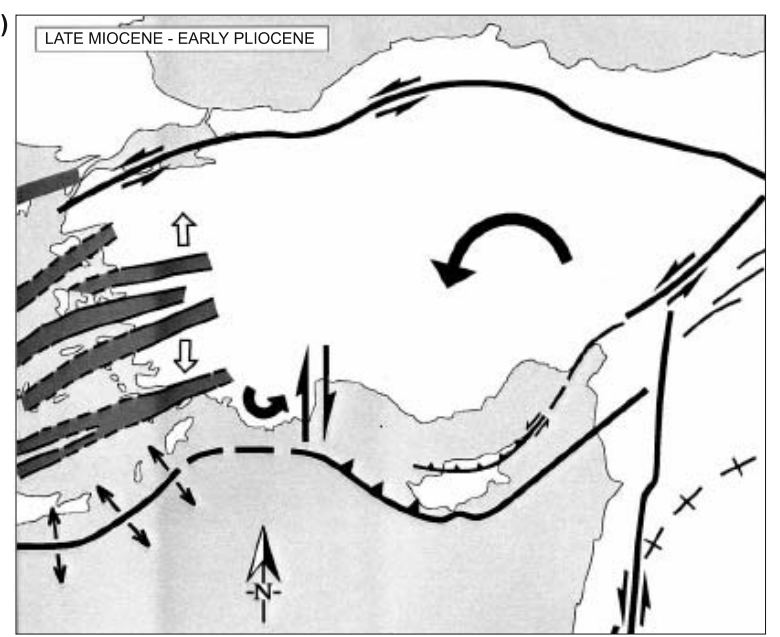

(b)

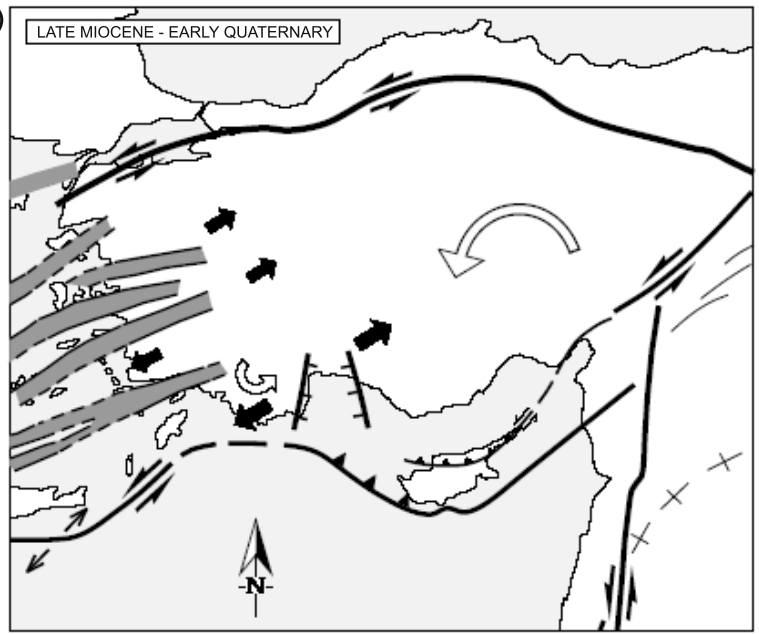

Figure 3. Tectonic regime of the Isparta Angle during (a) Late Miocene to Early Pliocene and (b) Late Miocene and Early Quaternary time (Glover and Robertson 1998).

the shear wave splitting parameters (polarization of fast wave, $\phi$ and delay time between fast and slow waves, $\delta t$ ) for the study area. Secondly, we have suggested a model for the mantle anisotropy beneath the Isparta Angle by using the results of previous model studies and results obtained from the geophysical and geologic data (Brechner et al 1998; Piromallo and Morelli 2003; Al-Lazki et al 2004; Sapaş and Boztepe-Güney 2005; Dolmaz et al 2005; Allmendinger et al 2007). Thirdly, we have compared our results on the investigation of the anisotropic mantle model beneath the Isparta
Angle with the ones beneath the Aegean region and eastern Anatolia (Hatzfeld et al 2001 and Sandvol et al 2003).

\section{Data and method}

In this study, we have used a broadband $(0.01-50 \mathrm{~Hz})$ Mednet/GEOPHONE seismograph station, ISP (Isparta), in southwestern Turkey (latitude $37.82^{\circ} \mathrm{N}$, longitude $30.52^{\circ} \mathrm{E}$ ). Data are obtained from IRIS archive through Wilber II 
utility. The sampling rate of the three-component records is 20 samples per second. Out of 357 teleseismic earthquakes that occurred between 1996 and 2006, we have selected shear wave seismograms of 21 events (table 1), which have a sufficiently high signal-to-noise ratio. The earthquake parameters of the selected events are mainly: magnitude $\geq 5.8$, depth $\geq 65 \mathrm{~km}, 86^{\circ} \leq$ epicenter distance $\leq 117^{\circ}$ and $127^{\circ} \leq$ backazimuth $\leq 280^{\circ}$.

At the high strain associated with the flow near the ridges and subduction zones, dislocation creep is the most important mechanism producing the preferred orientation of olivine crystals in the mantle (Ribe 1989). As a result of progressive simple shear, the fast direction of olivine, which is the crystallographic a-axis, aligns along the flow direction. Since olivine is a highly anisotropic and abundant mineral in the mantle, seismic anisotropy in the mantle is mainly controlled by the preferred orientation of olivine. A commonly accepted simple model for the upper mantle anisotropy is a localized single homogeneous layer beneath the receiver having hexagonal symmetry with a horizontal symmetry axis. For this model, investigating the existence of SKS splitting in the upper mantle is the most effective way to study the upper mantle anisotropy beneath the receivers (Silver and Chan 1988; Savage et al 1990; Teanby et al 2004). The SKS phases travel through the outer core as compression waves and emerge into the mantle as shear waves possessing nearly vertical mantle paths for even the most distant earthquakes. If the upcoming SKS ray path emerges into an anisotropic region in the upper mantle, S-wave splitting occurs and the separated two components of the SKS wave polarize at a right angle from each other and travel with different velocities.

In general, splitting correction method (Silver and Chan 1988; Vinnik et al 1992) is used to calculate the shear wave splitting parameters; fast polarization direction $(\phi)$ and delay time $(\delta t)$ between the fast and slow shear waves. In this method, calculated $\phi$ and $\delta t$ are sensitive to the choice of manually selected shear wave analysis window. Therefore, we have preferred a technique with automated selection of the window based on a grid search over the range of window lengths to find stable splitting measurements with small errors (Teanby et al 2004). We have used the following five steps to determine $\phi$ and $\delta t$ from SKS and SKKS phases on the seismograms of the selected earthquakes recorded at ISP station. Since the limitation of station and earthquake distributions for using SKS phases requires including other phases into the calculations to fill the backazimuthal gap, we have included the SKKS phases, which bounce once from the underside of the core-mantle boundary, of three events given in table 1. After the data selection step, we have first filtered the noisy seismograms by using a Butterworth band-pass filter $(0.03-0.2 \mathrm{~Hz})$ to improve the signal-to-noise ratio. Second, we have identified the phases (SKS or SKKS) on the seismograms. Third, we have cut and prepared the data for the analysis. Fourth, we have performed the splitting analysis (Teanby et al 2004 ) to calculate $\phi$ and $\delta t$ for a range of window lengths. Fifth, we have obtained parameters, which are stable over the different windows. If anisotropy exists, particle motion diagram of the radial and transverse components of the shear waves is elliptical (lower diagram on the left, figure $4 \mathrm{c}$ ). Thus, the selected splitting parameters $(\phi$ and $\delta t)$ should provide the best linearization on the particle motion diagram (lower diagram on the right, figure 4c) of the corrected radial and transverse components of the shear waves (corrected $R$ and $T$ in figure $4 \mathrm{~b}$ ). The $\phi$ and $\delta t$ pair with the lowest error (plus sign in figure 4d) minimizing the energy on the transverse component ( $T$ and corrected $T$ in figure $4 \mathrm{a}$ and $4 \mathrm{~b}$, respectively) is calculated. The obtained splitting parameters $(\phi$ and $\delta t)$ for the selected 21 earthquakes recorded at ISP station are given in table 1.

\section{Results and discussions}

The observed splitting parameters at ISP station ( $\phi$ and $\delta t$ ) are shown with filled triangles as a function of backazimuth in figure 5(a) and (b) and rose diagrams in figure 6 . The fast polarization directions, $\phi$ show two distinct groups $\left(82^{\circ}\right.$ and $\left.162^{\circ}\right)$ in the interval of backazimuth between $127^{\circ}$ and $280^{\circ}$. The delay times show both a great scatter and an increase from $0.37 \mathrm{~s}$ up to $4 \mathrm{~s}$ in the same backazimuthal interval. The observed splitting parameters $(\phi$ and $\delta t)$ at ISP station present a backazimuthal dependency although the method used in this study (Teanby et al 2004) is based on the assumption of one layer anisotropic model with a horizontal symmetry axis. This indicates an anisotropic complexity in the mantle, which may be caused by laterally varying anisotropy, dipping axis of symmetry other than horizontal symmetry axis, different forms of symmetry other than hexagonal, the effect of incidence angle, multiple layers of anisotropic media with different symmetry axes (Özalaybey and Savage 1994). Before we suggest a model for the mantle beneath the Isparta Angle based on the results of shear wave splitting studies, we first examined the results of previous studies given below and used them as additional information in our forward modeling studies.

Brechner et al (1998) have investigated the resolving power of the SKS technique for complicated anisotropic structures such as multilayer 
Table 1. List of the selected earthquakes used in this study and calculated splitting parameters (fast polarization direction, $\phi$ and delay time, $\delta t$ ) for ISP station.

\begin{tabular}{lcrrrrrrrr}
\hline $\begin{array}{l}\text { Date } \\
\text { (d.m.y) }\end{array}$ & $\begin{array}{c}\text { Origin_time } \\
\text { (hour:min:sec) }\end{array}$ & $\begin{array}{c}\text { Dist. } \\
\text { (deg.) }\end{array}$ & $\begin{array}{c}\text { Lat. } \\
\text { (deg.) }\end{array}$ & $\begin{array}{c}\text { Long. } \\
\text { (deg.) }\end{array}$ & $\begin{array}{c}\text { Baz. } \\
(\text { deg. })\end{array}$ & $\begin{array}{c}\text { Mag. } \\
(\text { Mw, Ms })\end{array}$ & $\begin{array}{c}\text { Depth } \\
(\mathrm{km})\end{array}$ & $\begin{array}{c}\phi \\
(\text { deg. })\end{array}$ & $\begin{array}{c}\delta t \\
(\mathrm{sec})\end{array}$ \\
\hline 02.11 .1996 & $00: 08: 50.6$ & 92 & $7.56 \mathrm{~S}$ & $117.30 \mathrm{E}$ & 127 & 5.8 & 302 & 75 & 3.20 \\
23.01 .1997 & $02: 15: 22.9$ & 107 & $22.0 \mathrm{~S}$ & $65.72 \mathrm{~W}$ & 235 & 7.1 & 276 & 110 & 0.95 \\
19.02 .1997 & $18: 25: 12.5$ & 100 & $4.56 \mathrm{~N}$ & $76.49 \mathrm{~W}$ & 230 & 5.8 & 101 & 56 & 2.40 \\
22.12 .1997 & $02: 05: 50.0$ & 114 & $5.50 \mathrm{~S}$ & $147.87 \mathrm{E}$ & 129 & 7.2 & 179 & 205 & 1.27 \\
05.04 .1999 & $11: 08: 04.0$ & 116 & $5.59 \mathrm{~S}$ & $149.57 \mathrm{E}$ & 129 & 7.4 & 150 & 69 & 1.60 \\
26.02 .2000 & $18: 24: 39.2$ & 98 & $9.41 \mathrm{~N}$ & $78.53 \mathrm{~W}$ & 229 & 6.1 & 65 & 179 & 3.95 \\
03.03 .2000 & $22: 09: 13.7$ & 100 & $7.32 \mathrm{~S}$ & $128.49 \mathrm{E}$ & 127 & 6.3 & 142 & 80 & 0.45 \\
23.04 .2000 & $09: 27: 23.3$ & 109 & $28.31 \mathrm{~S}$ & $62.99 \mathrm{~W}$ & 236 & 7.0 & 609 & 176 & 4.00 \\
23.04 .2000 & $17: 01: 17.4$ & 109 & $28.38 \mathrm{~S}$ & $62.94 \mathrm{~W}$ & 236 & 6.1 & 610 & 182 & 1.12 \\
12.05 .2000 & $18: 43: 18.1$ & 109 & $23.55 \mathrm{~S}$ & $66.45 \mathrm{~W}$ & 236 & 7.2 & 225 & 180 & 4.00 \\
16.06 .2000 & $07: 55: 35.3$ & 117 & $33.88 \mathrm{~S}$ & $70.09 \mathrm{~W}$ & 241 & 6.4 & 120 & 185 & 3.75 \\
21.06 .2000 & $16: 25: 06.3$ & 99 & $14.11 \mathrm{~N}$ & $144.96 \mathrm{E}$ & 133 & 5.9 & 112 & 190 & 1.00 \\
04.10 .2000 & $14: 37: 44.15$ & 86 & $11.12 \mathrm{~N}$ & $62.56 \mathrm{E}$ & 280 & 6.1 & 110 & 86 & 3.30 \\
14.03 .2001 & $18: 56: 18.8$ & 90 & $0.45 \mathrm{~N}$ & $121.89 \mathrm{E}$ & 127 & 5.9 & 109 & 85 & 2.00 \\
29.06 .2001 & $18: 35: 51.9$ & 106 & $19.52 \mathrm{~S}$ & $66.25 \mathrm{~W}$ & 235 & 6.1 & 274 & 69 & 0.37 \\
12.10 .2002 & $20: 09: 11.3$ & 104 & $8.26 \mathrm{~S}$ & $71.53 \mathrm{~W}$ & 233 & 6.8 & 536 & 182 & 1.80 \\
27.04 .2003 & $22: 57: 43.7$ & 104 & $8.14 \mathrm{~S}$ & $71.51 \mathrm{~W}$ & 233 & 5.9 & 546 & 110 & 0.95 \\
04.08 .2003 & $04: 37: 20.1$ & 115 & $60.53 \mathrm{~S}$ & $43.41 \mathrm{~W}$ & 212 & 7.5 & 10 & 176 & 1.75 \\
21.08 .2003 & $12: 12: 50.9$ & 147 & $45.18 \mathrm{~S}$ & $167.12 \mathrm{E}$ & 117 & 7.0 & 33 & 144 & $2.10^{*}$ \\
02.11 .2004 & $10: 02: 12.8$ & 91 & $49.28 \mathrm{~N}$ & $128.77 \mathrm{~W}$ & 347 & 6.6 & 10 & 87 & $3.62^{*}$ \\
02.01 .2006 & $06: 10: 49.2$ & 107 & $60.93 \mathrm{~S}$ & $21.58 \mathrm{~W}$ & 203 & 7.4 & 10 & 72 & $3.70^{*}$ \\
\hline
\end{tabular}

* Indicates that SKKS phase was used for the splitting analysis.

anisotropy and/or inclined symmetry axes. They have suggested that observed splitting parameters obtained under the assumption of one layer are apparent splitting parameters for a multilayer case but they are still meaningful. They have presented examples for the backazimuthal variations of the splitting parameters for incidence in inclined single anisotropic layer (model A), for vertical incidence in a system of two horizontal anisotropic layers (model B) and for non-vertical incidence in a system of two dipping anisotropic layers and symmetry axes (model C). They have observed the following on the calculated splitting parameters:

- The fast polarization directions show no backazimuthal variation for model $\mathrm{A}$, monotonous increase including jumps with $90^{\circ}$ periodicity for model $\mathrm{B}$ and irregular increase including jumps for model C.

- The delay times between the fast and slow waves show polynomial variations as a function of backazimuth for model $\mathrm{A}$, harmonic variations as a function of backazimuth with $90^{\circ}$ periodicity for model $\mathrm{B}$ and irregular and non harmonic variations as a function of backazimuth for model C.

- The splitting parameters depend on the frequency of the incident wave.
Since we have a limited backazimuthal coverage in our dataset, we have preferred to start with a simple model for the mantle anisotropy beneath the Isparta Angle. Therefore, model B presented by Brechner et al (1998) is an appropriate one for our model studies for the observed apparent splitting parameters at ISP station.

Global $P$-wave model of tomographic images presented by Piromallo et al (2003) have shown that the deep slab beneath the Bitlis-Zagros collisional belt is not continuous towards west. The slab is detached from its upper part beneath the belt and the rupture is prolonged to the west till Cyprus and to the eastern end of the Hellenic arc. This mechanism is possibly responsible for the MiocenePlioecene re-organization in the Anatolian-Aegean region and westward escape of Anatolia (Facenna et al 2006). The results of $P$-wave model of tomographic images in the region have indicated that an inclined single anisotropic mantle model may not work for the mantle beneath the Isparta Angle.

A measure of azimuthal anisotropy in the upper most and entire mantle is obtained from Pn anisotropy and SKS splitting results (Savage 1999). Al-Lazki et al (2004) have mapped Pn wave velocity and anisotropy structures at the junction of the Arabian, Eurasian and African plates (figure 7). They have found that the fast 


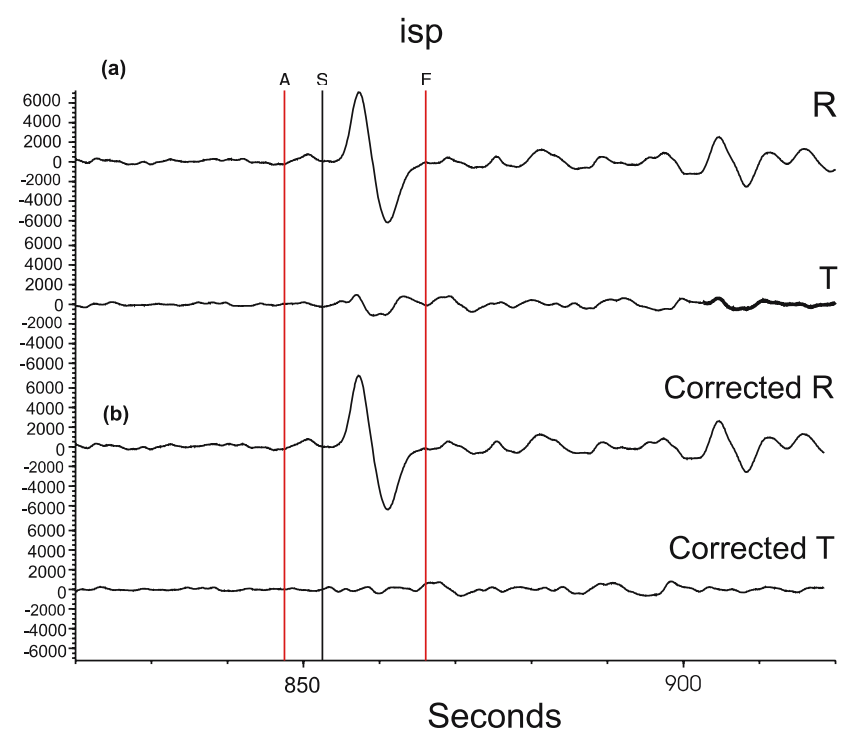

(c)

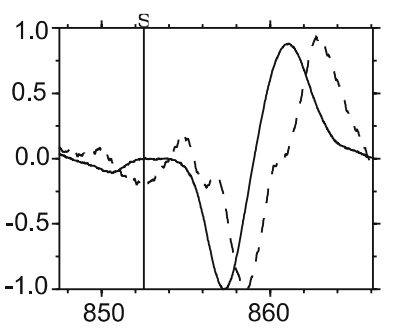

isp
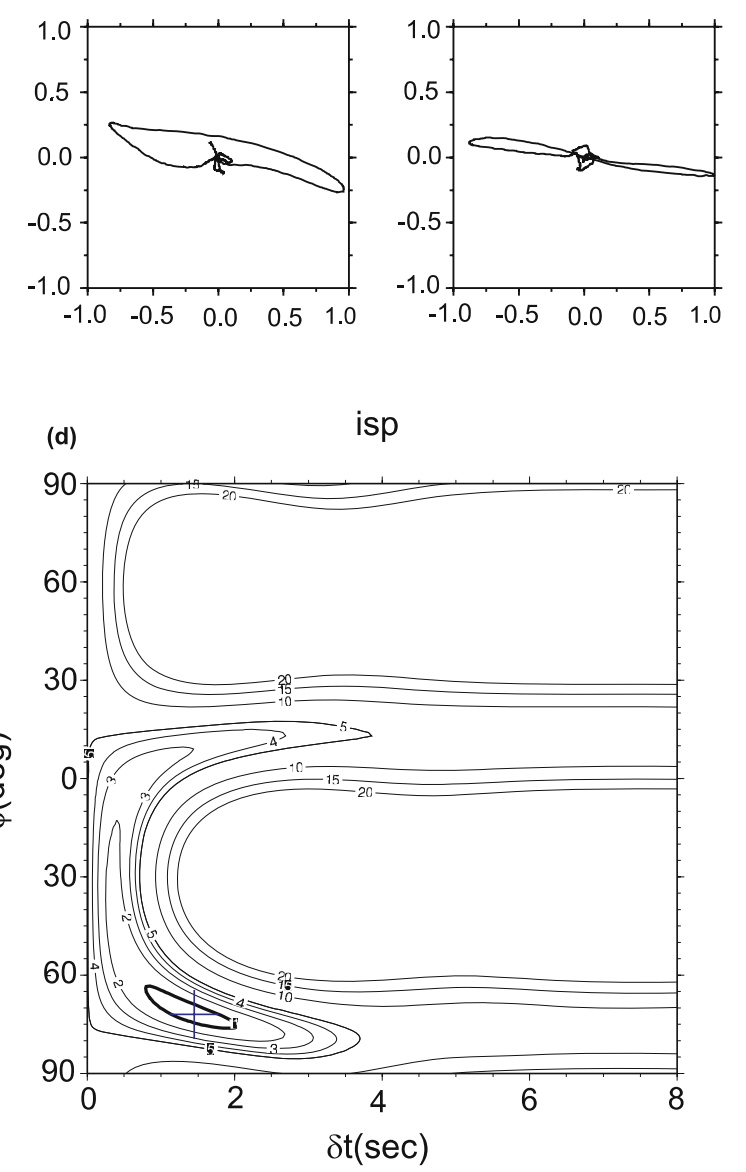

axes of Pn anisotropy within the Anatolian plate are predominantly $\mathrm{E}-\mathrm{W}$ in the east, $\mathrm{N}-\mathrm{S}$ at the center and $\mathrm{E}-\mathrm{W}$ in the west. They have shown that the fast axes of Pn anisotropy along the strike of the NAF change from NE-SW in the east to E-W and $\mathrm{N}-\mathrm{S}$ in the center and to NW-SW in the west of the Sea of Marmara. Figure 7 shows the lack of correlation between westward plate motion and sudden variations of the fast axes of Pn anisotropy beneath the Anatolian plate. This figure also shows that there is no match between the azimuthal Pn anisotropy and the polarized anisotropy of SKS fast splitting directions in eastern Anatolia. Al-Lazki et al (2004) have observed that localized anisotropy orientations are underlined by very low Pn velocity zones $(\mathrm{Pn}<7.8 \mathrm{~km} / \mathrm{s})$ such as northern Aegean zone and the Isparta Angle. They have suggested that there is a complex process including crustal and upper mantle deformation beneath the Arabian plate. The results of Pn tomography study (Al-Lazki et al 2004) have indicated that the fast axis direction of the upper mantle anisotropy beneath the Isparta Angle is approximately N-S.

Dolmaz et al (2005) have investigated the thermal structure of southwestern Turkey by using Curie Point Depth (CPD) estimates from the aeromagnetic data. They have suggested that a NNW-SSE trending belt of deep CPD region separates two shallow CPD zones and that the processes related to the African-Eurasion plate convergence zone control the regional thermal structure of southwestern Turkey. They have also shown the deepening CPD towards the active margin of Eurasia and have interpreted this as the cooling effect of the subducting old crust around $100-150 \mathrm{~km}$. The results of the estimated CPD values (Dolmaz et al 2005) have indicated that the thermal conditions of the upper mantle beneath the Isparta Angle are suitable for creating a 'frozen-in' anisotropy from a past tectonic episode (Vinnik et al 1992).

An accurate deformation pattern, which is consistent with long-term geologic features over a large area, can be obtained from the GPS vectors. Allmendinger et al (2007) have shown that

Figure 4. (a) Radial $(R)$ and transverse $(T)$ components of the data recorded at ISP station, (b) corrected waveforms of $R$ and $T$ components after splitting correction, (c) fast and slow shear waveforms before correction (top, left) and their particle motion (bottom, left) and fast and slow shear waveforms after correction (top, right) and their particle motion (bottom, right), (d) best fitting $\phi$ and $\delta t$ pair (cross symbol) determination is based on a grid search method which provides the best linearization on the particle motion diagram. The contour values range from 1 to 20 with intervals of 5 (thick curved lines) and 1 (thin curved lines). 

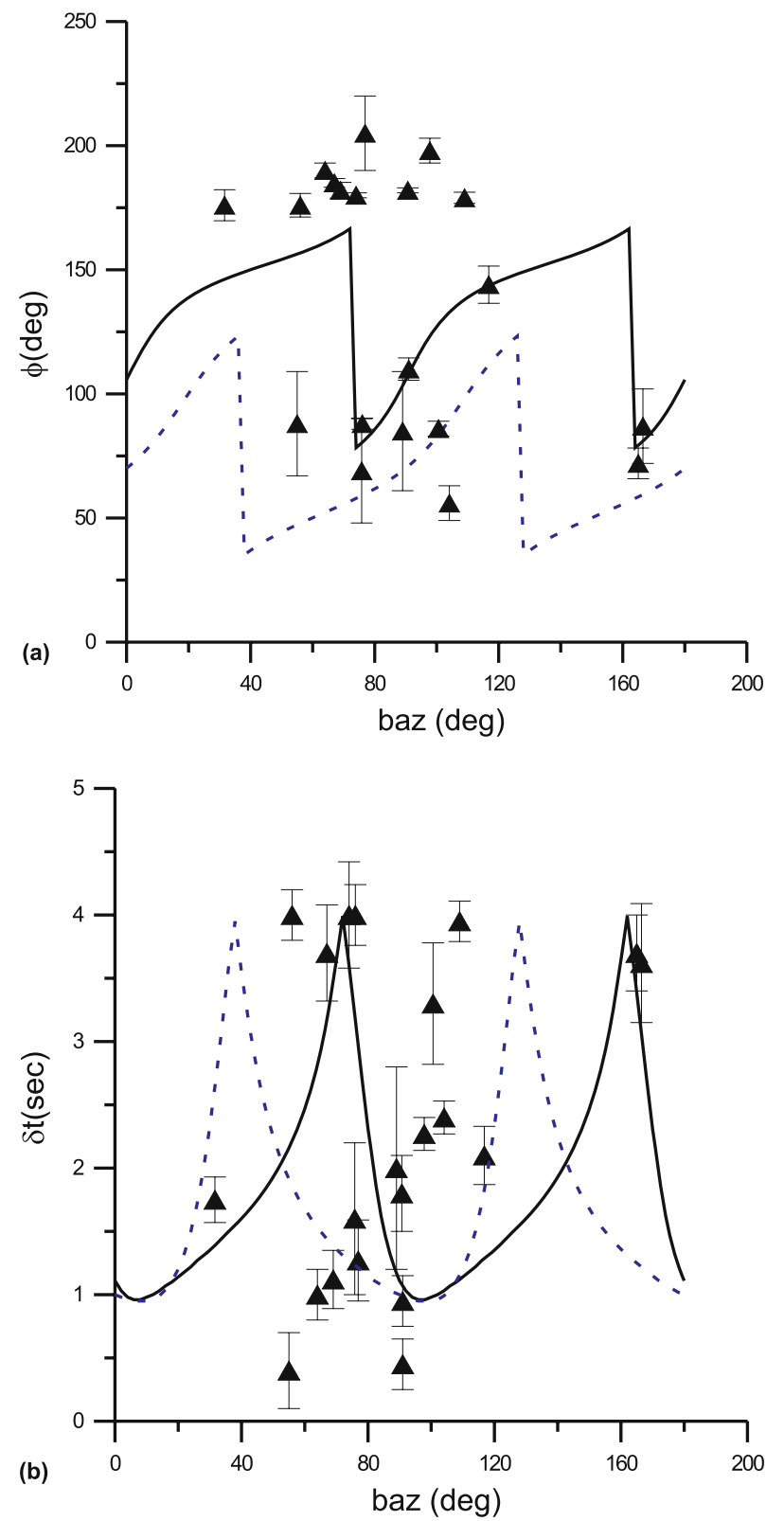

Figure 5. (a) Calculated apparent splitting parameters (filled triangles); fast polarization directions $(\phi)$ and (b) delay time $(\delta t)$ versus backazimuth (baz) moduli $\pi$ from the station ISP with error bars. Solid curves show splitting parameters for the best fitting forward model with two-layer mantle anisotropy with horizontal symmetry axis (upper layer: $\phi_{u}=150^{\circ}, \delta t_{u}=1.6 \mathrm{~s}$, lower layer: $\left.\phi_{l}=40^{\circ}, \delta t_{l}=1 \mathrm{~s}\right)$ minimizing the errors between observed and calculated splitting parameters $\left(\phi_{\mathrm{rms}}=46.31^{\circ}\right.$ and $\delta t_{\mathrm{rms}}=1.42 \mathrm{~s}$ ). Dashed curves show splitting parameters for one of the non-fitting forward models with two-layer mantle anisotropy with horizontal symmetry axis (upper layer; $\phi_{u}=70.0^{\circ}, \delta t_{u}=1.0 \mathrm{~s}$, lower layer; $\phi_{l}=180.0^{\circ}, \delta t_{l}=1.0 \mathrm{~s}$, $\phi_{\mathrm{rms}}=84.09^{\circ}$ and $\left.\delta t_{\mathrm{rms}}=1.68 \mathrm{~s}\right)$.

Anatolia has regions of positive dilatation on the outboard sides of the rotating blocks. They have concluded that positive dilatation observed in the Aegean region correlates with a region of crustal thinning and the rotation of Anatolia is related to the rollback of the Hellenic trench (figure 8). In this study, we have assumed that the anisotropy at deeper levels of the mantle beneath the Isparta Angle may be caused by recent deformation in the asthenosphere (Vinnik et al 1992).

Based on the results of previous studies, our study and assumptions given above, we have considered a two-layer anisotropic model with a horizontal symmetry axis for the mantle beneath the Isparta Angle. Our proposed model for mantle anisotropy beneath the Isparta Angle consists of 'frozen-in' anisotropy in the upper mantle and anisotropy caused by the asthenospheric flow. The 'frozen-in' anisotropy in the upper mantle beneath the Isparta Angle is a remnant of the past deformational episode of the Aegean extensional regime in $\mathrm{N}-\mathrm{S}$ direction (figure 3a), which was active in Late Miocene to Early Pliocene time (Glover and Robertson 1998). The anisotropy caused by the asthenospheric flow is a result of changing stress regime from $\mathrm{N}-\mathrm{S}$ to $\mathrm{NE}-\mathrm{SW}$ that occurred on the Aegean province around Late Pliocene-Early Quaternary time (Faccenna et al 2006). Based on the strain field obtained from GPS vectors (figure 8), we have considered that the crust is also under the effect of stress regime in the direction of NE-SW similar to the asthenospheric flow. We have investigated the validation of our proposed model for the mantle anisotropy beneath the Isparta Angle by using forward modeling technique for a simple two-layer anisotropic model with a horizontal symmetry axis (Savage et al 1990; Özalaybey and Savage 1994; Silver and Savage 1994).

Inspite of a limited range of backazimuthal coverage of the observed splitting parameters at ISP station, we have searched for possible solutions to minimize errors between the observed and calculated splitting parameters for a simple two-layer anisotropic model with a horizontal symmetry axis, by using the standard least squares method. We have constrained the splitting parameters of the lower layer of our proposed model to decrease the number of possible solutions. We have obtained the constraints from results of our previous shear wave splitting studies for ANTO, Ankara (latitude, $36.90^{\circ} \mathrm{N}$; longitude, $30.65^{\circ} \mathrm{E}$ ) and ISK, İstanbul (latitude, $41.07^{\circ} \mathrm{N}$; longitude, $29.06^{\circ} \mathrm{E}$ ) stations, which are 230 and $379 \mathrm{~km}$ away from ISP station (Sapaş and Boztepe-Güney 2005). Figure 6 shows the average splitting parameters at ANTO $\left(\phi=43^{\circ} \pm 8^{\circ}, \delta t=0.74 \mathrm{~s}\right)$ and ISK $\left(\phi=43.7^{\circ} \pm 5^{\circ}, \delta t=1.96 \mathrm{~s}\right)$ stations. The splitting parameters at ANTO and ISK stations show no backazimuthal variations suggesting one layer anisotropy model with a horizontal symmetry axis. Şapaş and Boztepe-Güney (2005) have suggested that the crust deforms similarly to the asthenospheric flow direction in this region based 


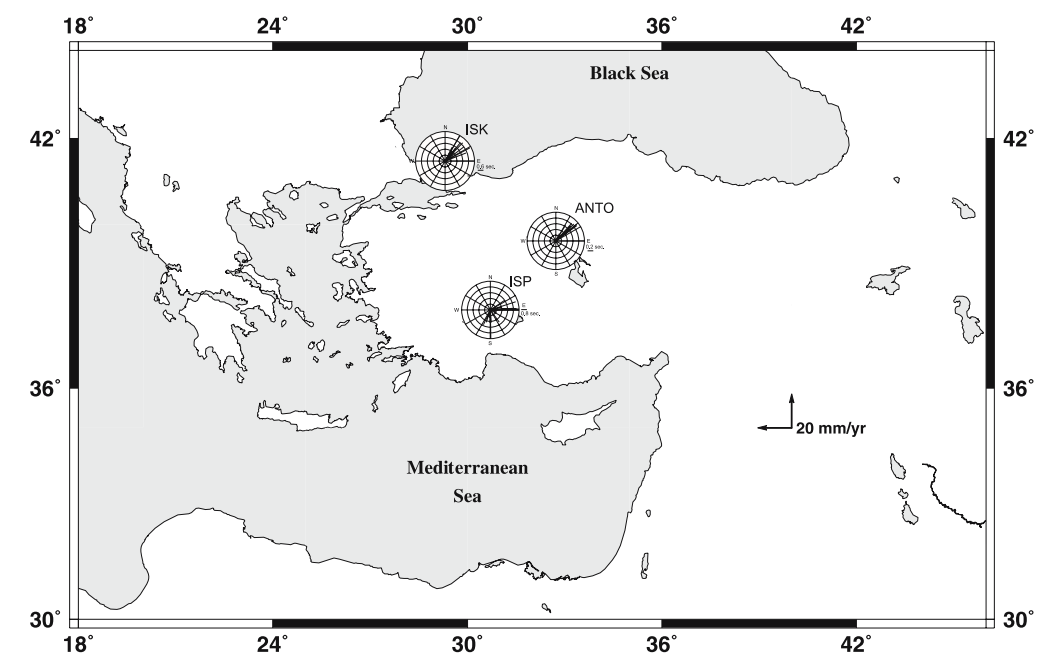

Figure 6. Map showing averaged fast directions and delay times beneath ISP, ANTO and ISK stations on rose diagrams (Şapaş and Boztepe-Güney 2005).

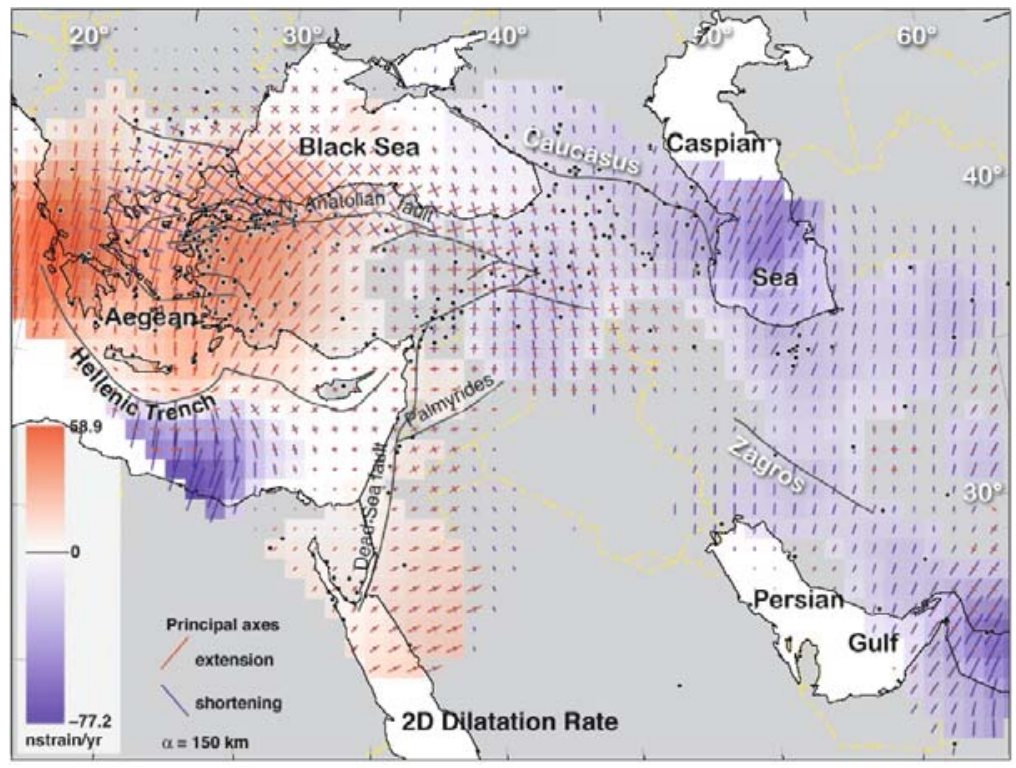

Figure 7. Map of GPS strain for eastern Mediterranean/Middle East. Short coloured line segments by the absolute value of their magnitude show the principal infinitesimal horizontal strain axes. Red and blue colours indicate extension and shortening (Allmendinger et al 2007).

on the strain deduced from the GPS displacements (Allmendinger et al 2007). Similar results have been suggested by Hatzfeld et al (2001) for the Aegean area.

We have searched for forward models of twolayer mantle anisotropy with a horizontal symmetry axis beneath ISP station with different splitting parameters by using analytical equations given by Silver and Savage (1994). We have also used the average splitting parameters calculated at ANTO and ISK stations (Şapaş and Boztepe-Güney 2005) as constraints for the splitting parameters of the lower layer of our proposed model $\left(\phi=43^{\circ}, \delta t=1 \mathrm{~s}\right)$. We have investigated the root mean square (rms) errors of pairs of calculated splitting parameters $(\phi, \delta t)$ for 3640 forward models of two-layer mantle anisotropy with a horizontal symmetry axis (Özalaybey and Savage 1994). The range of parameters used in the forward modeling studies are, for upper layer: $0.0^{\circ} \leq \phi \leq 180.0^{\circ}$, $\Delta \phi=2.0^{\circ} ; 0.1 \mathrm{~s} \leq \delta t \leq 4.0 \mathrm{~s}, \Delta \delta t=0.1 \mathrm{~s}$ and for lower layer: $\phi=40^{\circ}, \quad \delta t=1 \mathrm{~s}$, and dominant frequency $=0.125 \mathrm{~Hz}$. The splitting parameters for the best fitting forward model minimizing the rms errors $\left(\phi_{\mathrm{rms}}=46.31^{\circ}\right.$ and $\left.\delta t_{\mathrm{rms}}=1.42 \mathrm{~s}\right)$ are, lower layer $(l): \phi_{l}=40.0^{\circ}, \delta t_{l}=1.0 \mathrm{~s}$; upper 


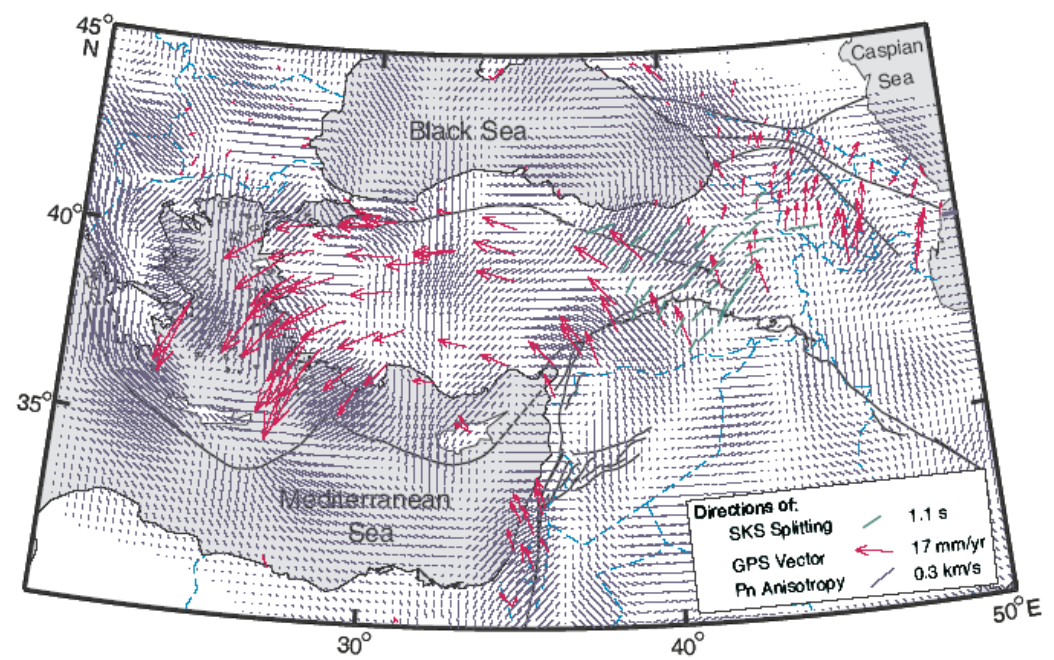

Figure 8. Map of Pn anisotropy in solid blue lines (Al-Lazki et al 2004), SKS shear wave splitting in solid green lines (Sandvol et al 2003) and GPS vector direction in solid pink lines (McClusky et al 2000).

layer $(u): \phi_{u}=150.0^{\circ}, \delta t_{u}=1.6 \mathrm{~s}$. In figure $3(\mathrm{a})$ and (b), we have plotted the observed (filled triangles) and the calculated splitting parameters as a function of backazimuth for the best fitting forward model (solid curve) together with one of the non-fitting forward models, $\phi_{l}=180.0^{\circ}, \quad \delta t_{l}=1.0 \mathrm{~s} ; \quad \phi_{u}=70.0^{\circ}, \quad \delta t_{u}=1.0 \mathrm{~s}$ with $\phi_{\mathrm{rms}}=84.09^{\circ}, \delta t_{\mathrm{rms}}=1.68 \mathrm{~s}$ (dashed curve).

The thickness of a localized anisotropic layer $(L)$ for the fractional difference in velocity between the fast and slow directions $(\varepsilon \ll 1)$ is defined by $L=\delta t \beta / \varepsilon$ assuming a localized anisotropic material with constant shear velocity $(\beta)$ and a ray path with vertical incidence angle (Silver and Chan 1988). If we assume $\beta=4.6 \mathrm{~km} / \mathrm{s}$ and $\varepsilon=0.04$ for the upper mantle (Crampin and Booth 1985), the calculated delay times, $\delta t_{l}=1, \delta t_{u}=1.6 \mathrm{~s}$ correspond to anisotropic layers about 115 and $184 \mathrm{~km}$ thick.

In this study, we have suggested a two-layer anisotropic model with a horizontal symmetry axis for mantle anisotropy beneath the Isparta Angle consisting of 'frozen-in' anisotropy in the upper mantle $\left(\phi_{u}=150.0^{\circ}, \delta t_{u}=1.6 \mathrm{~s}\right)$ and anisotropy caused by the asthenospheric flow $\left(\phi_{l}=40.0^{\circ}\right.$, $\left.\delta t_{l}=1.0 \mathrm{~s}\right)$. We have suggested that the crust is also under the effect of stress regime in the direction of NE-SW similar to asthenospheric flow. The 'frozen-in' anisotropy in the upper mantle $\left(\phi_{u}=150.0^{\circ}, \delta t_{u}=1.6 \mathrm{~s}\right)$ beneath the Isparta Angle is related to the tectonic evolution of the region in Late Miocene to Early Pliocene time (figure 3a). In this time of period, the Isparta Angle was situated between the Aegean extensional province $(\mathrm{N}-\mathrm{S})$ and the rotational movement of the Anatolian plateau and experienced right lateral shear (Glover and Robertson 1998). The asthenospheric flow $\left(\phi_{l}=40.0^{\circ}, \delta t_{l}=1.0 \mathrm{~s}\right)$ beneath the Isparta Angle is a result of a change in stress regime from $\mathrm{N}-\mathrm{S}$ to $\mathrm{NE}-\mathrm{SW}$ that occurred on the Aegean province around Late PlioceneEarly Quaternary time (figure $3 \mathrm{~b}$ ).

In the east of the Isparta Angle, Sandvol et al (2003) have investigated the shear wave splitting for eastern Turkey. They have found that the fast polarization directions are relatively uniform and exhibit mainly NE-SW directions and the observed delay time range from 0.7 to $2.0 \mathrm{~s}$. They have suggested that there is a fundamental difference in the asthenospheric flow directions and surface deformation across the Arabian and Anatolian plates. Also, they have suggested that large surface faults do not have any influence on the upper mantle flow patterns or deformations in the area. In the west of the Isparta Angle, Hatzfeld et al (2001) have investigated the shear wave anisotropy in the upper mantle beneath the Aegean area. They have mapped the fast polarization direction of anisotropy superimposed on the strain deduced from the GPS measurements (McClusky et al 2000). They have shown that the fit is better in the northern Aegean Sea and western Turkey and have suggested that the crust and the upper mantle deform similarly in this region.

Since the Isparta Angle is at the boundary between central/eastern Anatolia and Aegean/ western deformation areas, it is expected that future shear wave splitting studies consisting of more data with a good backazimuthal coverage might give us detailed information about the anisotropic complexity beneath the Isparta Angle. 


\section{Acknowledgements}

We thank Teanby et al (2004), Goldstein et al (1999), and Wessel and Smith (1995) for allowing us to use ASS.f, SAC2000 and GMT software, respectively.

\section{References}

Allmendinger R W, Reilinger R and Loveless J 2007 Strain and rotation rate from GPS in Tibet, Anatolia and the Altiplano; Tectonics 26 TC3013, doi: 10.1029/ 2006TC002030.

Al-Lazki A I, Sandvol E, Seber D, Barazangi M, Türkelli N and Mohamad R 2004 Pn tomographic imaging of mantle lid velocity and anisotropy at the junction of the Arabian, Eurasian and African plates; Geophys. J. Int. 158 1024-1040.

Brechner S, Klinge K, Krüger F and Plenefisch T 1998 Backazimuthal variations of splitting parameters of teleseismic SKS phases observed at the broadband stations in Germany; Pure Appl. Geophys. 151 305-331.

Christensen N I 1984 The magnitude symmetry and origin of upper mantle anisotropy based on fabric analyses of ultramafic tectonites; Geophys. J. R. Astr. Soc. 76 89-111.

Crampin S and Booth D C 1985 Shear-wave polarization near the north Anatolian Fault II, Interpretation in terms of crack-induced anisotropy; Geophys. J. R. Astr. Soc. 83 75-92.

Dolmaz M N, Ustaomer T, Hisarli Z M and Orbay N 2005 Curie Point Depth variations to infer thermal structure of the crust at the African-Eurasian convergence zone, SW Turkey; Earth Planets Space 57 373-383.

Faccenna C, Bellier O, Martinod J, Piromallo C and Regard V 2006 Slab detachment beneath eastern Anatolia: A possible cause for the deformation of the North Anatolian fault; Earth Planet. Sci. Lett. 242 $85-97$.

Glover C and Robertson A 1998 Neotectonic intersection of the Aegean and Cyprus tectonic arcs: Extensional and strike-slip faulting in the Isparta Angle, SW Turkey; Tectonophys. 298 103-132.

Goldstein P, Dodge D and Firpo M 1999 SAC 2000: Signal processing and analysis tools for seismologists and engineers (UCRL-JC-135963); Invited contribution to the IASPEI, International Handbook of Earthquake and Engineering Seismology.

Hatzfeld D, Karagianni E, Kassaras I, Kiratzi A, Louvari E, Lyon-Caen H, Makropoulos K, Papadimitriou P, Bock G and Priestley K 2001 Shear wave anisotropy in the upper mantle beneath the Aegean related to internal deformation; J. Geophys. Res. 106 30,737-30,753.
McClusky S, Balassanian S, Barka A, Demir C, Ergintav S, Georgiev I, Gurkan O, Hamburger M, Hurst K, Kahle H, Kastens K, Kekelidze G, King R, Kotzev V, Lenk O, Mahmoud S, Mishin A, Nadariya M, Ouzounis A, Paradissis S, Peter Y, Prilepin M, Reilinger R, Sanli I, Seeger H, Tealeb A, Toksoz M and Veis G 2000 GPS constraints on plate motion and deformation in the eastern Mediterranean: Implications for plate dynamics; J. Geophys. Res. 105 5695-5719.

Özalaybey S and Savage M K 1994 Double-layer anisotropy resolved from S phases; Geophys. J. Intr. 117 653-664.

Piromallo C and Morelli A 2003 P wave tomography of the mantle under the Alpine-Mediterranean area; J. Geophys. Res. 108 doi: 10.1029/2002JB001757.

Reilinger R E, McClusky S C, Oral M B, King R W and Toksöz M N 1997 Global Positioning System measurements in the Arabia-Africa-Eurasia plate collision zone; J. Geophys. Res. 102 9983-9999.

Ribe N M 1989 Seismic anisotropy and mantle flow; J. Geophys. Res. 94 4213-4223.

Sandvol E, Türkelli N, Zor E, Gök R, Bekler $\mathrm{T}$ and Gürbüz C 2003 Shear wave splitting in a young continent-continent collision: An example from Eastern Turkey; Geophys. Res. Lett. 30 24, 8041, doi: 10.1029/ 2003GL017390.

Savage M K, Silver P G and Meyer R P 1990 Observations of teleseismic shear-wave splitting in the basin and range from portable and permanent stations; Geophys. Res. Lett. 17 21-24.

Savage M K 1999 Seismic anisotropy and mantle deformation: What have we learned from shear wave splitting?; Rev. Geophys. 37 65-106.

Silver P G and Chan W W 1988 Implications for continental structure and evolution from seismic anisotropy; Nature 335 34-49.

Silver P G and Savage M K 1994 The interpretation of shear-wave splitting parameters in the presence of two anisotropic layers; Geophys. J. Int. 119 949-963.

Şapaş A and Boztepe-Güney A 2005 The analysis of SKS splitting in western Turkey, International Earth Sciences Colloquium on the Aegean Region, IESCA 2005, Abstracts Book, Dokuz Eylül University, Engineering Faculty, Department of Geology, Izmir, Turkey, 4-7 October: 262.

Teanby N A, Kendall J M and van der Baan M 2004 Automation of shear-wave splitting measurements using cluster analysis; Bull. Seismol. Soc. Am. 94 453-463.

Vinnik L P, Makeyeva L I, Milev A and Usenko A Yu 1992 Global patterns of azimuthal anisotropy and deformations in the continental mantle; Geophys. J. Int. 111 $433-447$.

Wessel P and Smith W H F 1995 New version of the generic mapping tools (GMT) version 3.0 released; Trans. AGU, Eos 76329. 